\title{
Effect of Ozone Therapy (OT) on Healing of Colonic Anastomosis in a Rat Model of Peritonitis
}

\author{
Başak Erginel $^{1}$, Turgay Erginel ${ }^{2}$, Bilgin $\mathrm{Aksoy}^{3}$, Ali İhsan Dokucu ${ }^{1}$ \\ ${ }^{1}$ Department of Pediatric Surgery, İstanbul Şişli Etfal Training and Research Hospital, İstanbul, Turkey \\ ${ }^{2}$ Department of General Surgery, İstanbul Training and Research Hospital, İstanbul, Turkey \\ ${ }^{3}$ Department of Pathology, İstanbul Training and Research Hospital, İstanbul, Turkey
}

Background: Ozone is a three-oxygen molecule (O3). Ozone therapy (OT) is systematically effective when pathological inflammatory and immunologic processes are activated. Among of these conditions are wound healing, macular degeneration related to aging, and conditions that are ischemic or infectious.

Aims: The aim of this study was to determine the effects of OT on wound healing of intestinal anastomosis in the presence of peritonitis in a rat model.

Study Design: Animal experimentation.

Methods: A total of 40 Wistar albino rats were randomized into four groups $(\mathrm{n}=10)$ including: sham $(\mathrm{S})$, peritonitis $(\mathrm{P})$, ozone $0(\mathrm{O} 0)$, and ozone 24 (O24). In group S, only cecal dissection was carried out. The $\mathrm{S}$ group had only a cecal dissection and intestinal anastomosis performed, but no peritonitis. In all other groups, cecal ligation and puncture (CLP) followed the cecal dissection to induce bacterial peritonitis. $24 \mathrm{~h}$ after puncture, a cecal resection and ileocolic anastomosis were performed. In group P, $24 \mathrm{~h}$ after CLP, a cecal resection and ileocolic anastomosis were performed and no ozone was administered. In group O0, immediately after the anastomosis, and in group O24, starting 24 hours after the anastomosis, an intraperitoneal $1 \mathrm{mg}$ / $\mathrm{kg}$ /day ozone administration was applied for seven days. On the sev- enth day the animals were sacrificed, the anastomotic bursting pressures (BP) and the hydroxyproline values of the anastomotic tissues were measured, and histopathologic examination of the anastomotic segment was carried out.

Results: The highest BP was in group S, with $211 \pm 23.13 \mathrm{mmHg}$. The mean BP of group P was $141 \pm 56.25 \mathrm{mmHg}$, which was significantly lower than in the other two peritonitis groups that received ozone therapy, group $\mathrm{O} 0$ and $\mathrm{O} 24$, where it was $192 \pm 22$ and $166 \pm 45 \mathrm{mmHg}$, respectively $(\mathrm{p}<0.05)$. The difference in the BP between groups $\mathrm{O} 0$ and $\mathrm{O} 24$ was not statistically significant $(\mathrm{p}>0.05)$. Histopathologic analyses of the anastomotic segments determined there was significantly more oedema and necrosis in the control group rats, and collagen deposition in the anastomotic tissue was significantly higher in the ozone-treated groups on postoperative day 7. Hydroxyproline levels were significantly higher in groups $\mathrm{O} 0$ and $\mathrm{O} 24$ compared to the peritonitis group $(\mathrm{P})$.

Conclusion: Ozone therapy has a beneficial effect on anastomotic healing of the colon in the presence of peritonitis.

(Balkan Med J 2014;31:249-53).

Key Words: Anastomosis, colon, ozone, peritonitis, rat
Colonic resection and anastomosis is one of the most common operations in gastrointestinal surgery, both in children and adults. Although these are safe operations, an anastomosis leakage is a frequent problem $(1,2)$. Age, condition of the patient, colonic flora, inflammation and surgical techniques are the most important factors affecting the outcome of these procedures $(3,4)$. The presence of peritonitis is a defining factor of anastomosis integrity.

The cecal ligation and puncture (CLP) model was first defined by Hubbard et al. (5) in 1978 to induce peritonitis. Several studies suggest that in the presence of peritonitis, wound healing worsens and anastomotic leakage increases. To avoid these unwanted effects of peritonitis on wound healing and to increase anastomosis security, various methods and local or systemic agents are being investigated.

Ozone is a three-oxygen molecule $\left(\mathrm{O}_{3}\right)$. Ozone therapy (OT) is systematically effective when pathological inflammatory and immunologic processes are activated. Among these conditions are wound healing, macular degeneration related to aging, and conditions that are ischemic or infectious.

During OT, the gaseous mixture of oxygen and ozone exerts biological actions that may increase certain enzymes and cytokines. Ozone provides its protective effects via autacoids, cytokines, and growth factors. Recurrent OT corrects the dis- 
TABLE 1. Semiquantitative histopathological parameters used to analyse wound healing in the colon

\begin{tabular}{|c|c|c|c|c|c|c|c|c|c|c|}
\hline Score & Necrosis & $\begin{array}{l}\text { PMN } \\
\text { cells }\end{array}$ & $\begin{array}{c}\text { Mononuclear } \\
\text { Cells }\end{array}$ & Oedema & $\begin{array}{l}\text { Mucosal } \\
\text { Epithelium }\end{array}$ & $\begin{array}{l}\text { Submucosal/ } \\
\text { mucosal layer }\end{array}$ & $\begin{array}{l}\text { Granulation } \\
\text { Tissue }\end{array}$ & $\begin{array}{l}\text { Neoangio- } \\
\text { genesis }\end{array}$ & $\begin{array}{c}\text { Fibro- } \\
\text { blast }\end{array}$ & $\begin{array}{l}\text { Collagen } \\
\text { deposition }\end{array}$ \\
\hline 0 & None & $\begin{array}{l}\text { Normal } \\
\text { number }\end{array}$ & $\begin{array}{l}\text { Normal } \\
\text { number }\end{array}$ & None & $\begin{array}{l}\text { Normal } \\
\text { Glandular }\end{array}$ & $\begin{array}{c}\text { Good } \\
\text { bridging }\end{array}$ & None & None & None & None \\
\hline 1 & $\begin{array}{c}\text { Small } \\
\text { patches }\end{array}$ & $\begin{array}{c}\text { Slight } \\
\text { increase }\end{array}$ & $\begin{array}{c}\text { Slight } \\
\text { increase }\end{array}$ & Some & $\begin{array}{l}\text { Normal } \\
\text { cubic }\end{array}$ & $\begin{array}{l}\text { Average } \\
\text { bridging }\end{array}$ & Some & Partial & Partial & Partial \\
\hline 2 & $\begin{array}{c}\text { Some } \\
\text { patches }\end{array}$ & $\begin{array}{l}\text { Marked } \\
\text { infiltration }\end{array}$ & $\begin{array}{l}\text { Marked } \\
\text { infiltration }\end{array}$ & Marked & $\begin{array}{l}\text { Incomplete } \\
\text { cubic }\end{array}$ & $\begin{array}{c}\text { Poor } \\
\text { bridging }\end{array}$ & Marked & Moderate & Moderate & Moderate \\
\hline 3 & Massive & $\begin{array}{l}\text { Massive } \\
\text { infiltration }\end{array}$ & $\begin{array}{l}\text { Massive } \\
\text { infiltration }\end{array}$ & Severe & Absent & $\begin{array}{c}\text { No } \\
\text { bridging }\end{array}$ & Severe & Marked & Marked & Marked \\
\hline
\end{tabular}

turbed redox equilibrium by affecting the antioxidant system (6-10). Positive effects of OT on caustic oesophagus injuries have also been suggested (11).

The concept of using ozone to accelerate the healing of infected wounds, necrotic or low oxygenated tissue has been explored in orthopaedics, dentistry and skin wounds. The use of these therapeutics in the healing of colonic anastomosis was explored for the first time by Lelyanov et al. (12).

The aim of the present study was to determine the effects of OT on anastomotic healing in a rat peritonitis model.

\section{MATERIAL AND METHODS}

After obtaining instructional animal ethics committee approval, 40 male Wistar albino rats weighing 300-350 g were equally divided into four groups. They were housed in a temperature- $\left(21 \pm 2^{\circ} \mathrm{C}\right)$ and humidity-controlled environment with a 12-hour light/dark cycle. Each group contained ten rats. The groups included: sham (S), Peritonitis (P) (control), ozone 0 $(\mathrm{O} 0)$ and ozone $24(\mathrm{O} 24)$. In group $\mathrm{S}$, only cecal dissections were carried out. In the other groups, CLP followed the cecal dissection to induce bacterial peritonitis. We used the modified peritonitis model of Hubbard et al. (5) for this procedure. In group P, $24 \mathrm{~h}$ after the previous operation, a cecal resection and ileocolic anastomosis were performed. In group O0, immediately after cecal resection and ileocolic anastomosis, which had been performed 24 hours after the cecal dissection and anastomosis, $1 \mathrm{mg} / \mathrm{kg} / \mathrm{day}$ ozone was administered intraperitoneally for seven days. In group O24, 24 hours after peritonitis had been induced with the same method, intraperitoneal $1 \mathrm{mg} / \mathrm{kg} / \mathrm{day}$ ozone was administered for seven days. On the seventh postoperative day the animals were sacrificed the anastomosis bursting pressures (BP) were recorded and histopathologic analyses were performed.

\section{Bursting pressures}

On the seventh day the animals were sacrificed and the anastomotic bursting pressures (BP) were measured. We re- sected a $10 \mathrm{~cm}$ long bowel segment, situating the anastomosis in the middle part, and washed it with saline solution. We then ligated one end with 3/0 silk and connected the other end to a $8 \mathrm{~F}$ feeding tube. We connected a Y-shaped adapter at the end of the feeding tube. A sphyngomanometer (Petas, Turkey) and a $50 \mathrm{~mL}$ syringe were adapted to either end of the adapter. We submerged the bowel in the saline solution. We then insufflated the colonic segment with air. The bursting pressure was recorded at the time of the first air bubble. In all cases the bursting site was on the anastomosis. An anastomosis segment $1 \mathrm{~cm}$ in length was also fixed in formaldehyde solution (13).

\section{Pathological analysis}

Histopathological examination was performed blindly by a pathologist who was not aware of the study groups. After routine procedures, colonic segments were embedded in paraffin blocks. The paraffin blocks were cut into four micron-wide sections and these tissue sections were stained with haematoxylin and eosin. Histopathologic scoring was performed according to a scale previously used by Verhofstad et al. (14) and is shown in Table 1. Fibroblastic activity, neoangiogenesis, and a collagen deposition grading scale were used by Ehrlich and Hunt (15). The scale was used in the modified form where it was converted to a numerical system by Philips et al. (16).

\section{Hydroxyproline measurement}

One gram of the resected tissue containing the anastomotic segment was hydrolysed for five hours at $121^{\circ} \mathrm{C}$ in an acidic buffer solution. After the hydrolysis, the samples were centrifuged at $5000 \mathrm{rpm}$ for 20 minutes. The absorbance of the final material was evaluated by the colorimetric method at $560 \mathrm{~nm}$ and $121^{\circ} \mathrm{C}$ and the tissue hydroxyproline level was calculated as $\mathrm{mg} / \mathrm{L} / \mathrm{g}$ using a commercially available kit (Hydroxyproline Extra [Colorimetric determination], Brand; Far, Italy) (17).

\section{Statistical analysis}

Statistical Package for the Social Sciences (SPSS) software 15.0 version (SPSS, Inc, Chicago, IL, USA) statistical computer programme was used. Descriptive statistical meth- 
TABLE 2. Bursting pressure and standard deviation for all groups. The difference between the $\mathrm{BP}$ results in groups $\mathrm{O} 0$ and $\mathrm{O} 24$ was not statistically significant $(\mathrm{p}>0.05)$

\begin{tabular}{lcc}
\hline & Mean BP & SD \\
\hline Sham (S) & 211 & 23 \\
Peritonitis (P) & 141 & 25 \\
O0 (ozone 0) & 192 & 22 \\
O24 (ozone 24) & 166 & 45 \\
\hline
\end{tabular}

BP: bursting pressures; SD: standard deviation

TABLE 3. Histological scoring of the groups $(p<0.05)$

\begin{tabular}{lcccc}
\hline & $\mathrm{S}$ & $\mathrm{P}$ & $\mathrm{O} 0$ & $\mathrm{O} 24$ \\
\hline Necrosis & 3 & 3 & $0^{*}$ & $0^{*}$ \\
PMNL & 1 & 1 & $0^{*}$ & $0^{*}$ \\
MNL & 2 & 2 & 2 & 2 \\
Oedema & 3 & 3 & $1.5^{*}$ & $1.5^{*}$ \\
Mucosa & 2 & 2 & 2 & 2 \\
Submucosa & 2 & 2 & 2 & 2 \\
Granulation & 1 & 1 & 1 & 1 \\
Neoangiogenesis & 1 & 1 & 1 & 1 \\
Fibroblast & 2 & 2 & 2 & 2 \\
Collagen & 1.5 & 1 & $3^{*}$ & $3^{*}$ \\
\hline
\end{tabular}

PMN: polymorphonuclear lymphocytes; MNL: mononuclear lymphocytes

*There is statistical difference between the ozone treated groups and others $(\mathrm{p}<0.05)$

ods were used. ANOVA and $t$-tests were used to compare the group distributions and Kolmogorov-Smirnov and ShapiroWilk normality tests were used for the normality analyses. The Kruskal-Wallis test was used for the variance analysis and the Mann-Whitney $U$ test was used to compare those groups for which a normal distribution did not exist. Ninety-five percent was accepted as the confidence interval, and a $P$ value $\leq 0.05$ was considered significant for the analysis.

\section{RESULTS}

There was no mortality during the study. All rats showed intra-abdominal sepsis symptoms following CLP, such as anorexis, piloerection, and immobilization following inoculation.

\section{Body weight analysis}

In all groups with CLP, body weight decreased, especially in the first 24 hours after CLP. A body weight loss of $10 \%$ was similar between groups II-IV.

\section{Effects of ozone therapy on colonic anastomosis bursting pressures}

The BPs of all groups are shown in Table 2. The highest $\mathrm{BP}$ was in group $\mathrm{S}$, with $211 \pm 23 \mathrm{mmHg}$. The sham group only had a cecal dissection and anastomosis performed, but no peritonitis. The mean BP of group P was $141 \pm 25 \mathrm{mmHg}$, which was significantly lower than in the other two peritonitis groups that received ozone therapy, group $\mathrm{O} 0$ and $\mathrm{O} 24$, where it was $192 \pm 22$ and $166 \pm 45 \mathrm{mmHg}$, respectively $(\mathrm{p}<0.05)$. The difference between the BP results in groups $\mathrm{O} 0$ and $\mathrm{O} 24$ was not statistically significant $(\mathrm{p}>0.05$ ).

\section{Effects of ozone therapy on histopathologic values}

On the seventh postoperative day there were no significant differences between the groups in terms of submucosal/mucosal layer, mucosal epithelium, granulation tissue, and mononuclear cells $(\mathrm{p}>0.05)$. However, there were significant differences between the groups in terms of necrosis, oedema, and polymorphonuclear cells $(p<0.05)$. Necrosis and oedema were more severe and polymorphonuclear cell infiltration was higher in the control group than in the treatment groups. The collagen deposition at the anastomotic line was significantly higher in the ozone groups than in the control group. Compared with the group $\mathrm{S}$ and $\mathrm{P}$ rats, a marked collagen deposition was observed in the ozone groups after Masson's trichrome staining. The histological scoring of the groups are given in Table 3.

\section{Hydroxyproline level}

The mean hydroxyproline levels were $439 \pm 23.42 \mathrm{mg} / \mathrm{L} / \mathrm{g}$ in Group S, $123 \pm 22.32 \mathrm{mg} / \mathrm{L} / \mathrm{g}$ in Group P, $399 \pm 29.81$ in Group O0, and $345 \pm 85.45$ in Group O24. Hydroxyproline levels were significantly higher in groups $\mathrm{O} 0$ and $\mathrm{O} 24$ compared to the peritonitis group $(\mathrm{P})$. There were significant differences in the concentration of hydroxyproline when the $\mathrm{O} 0$ and $\mathrm{O} 24$ groups and the sham group were compared $(\mathrm{p}<0.05)$.

\section{DISCUSSION}

One of the most common complications of gastrointestinal operations is anastomotic leaks, which are associated with high morbidity and mortality rates. The anastomotic leak rate is reported at $10 \%$ to $20 \%$ (16).

Anastomotic strength with maintenance of luminal integrity is a fundamental necessity for a successful outcome of gastrointestinal surgery. Performing a primary anastomosis in a contaminated field is thought to be associated with a failure to heal, anastomotic dehiscence, and peritoneal soilage from gastrointestinal anastomoses. Various agents have been investigated to ameliorate these effects of peritonitis on colonic anastomoses. These agents include hyperbaric oxygen, glucan, erythropoietin, bosentan, growth hormone, and $\mathrm{H}_{2}$ antagonists like famotidine. All of these agents aim to reduce ischemia (18-23). OT increases tissue oxygenation by shifting the oxyhaemoglobin curve to the right. $\mathrm{H}_{2} \mathrm{O}_{2}$ formed by the OT causes the production of many growth factors, especially 
VEGF (24). We did not evaluate VEGF expression in the current study. This is a further topic of investigation in the future. OT is also an antioxidant agent when used at lower doses by supporting cellular antioxidant systems including glutathione and superoxide dismutase (SOD) (25). In this study, we demonstrated an elevated protective effect of OT on colonic anastomoses in the presence of peritonitis. We evaluated bursting pressures, histopathology, and hydroxyproline levels to measure the anastomotic healing process.

Bursting pressures is reported to be a reliable indicator for wound healing (26). It reveals the mechanical parameters of a colonic anastomosis and reflects growing anastomotic strength (27). The protective effect of OT on wound healing of colonic anastomoses in the presence of bacterial peritonitis is supported by the BP results.

During wound healing, collagen is important in giving strength and integrity to the anastomosis. On the fifth and seventh days following an anastomosis, collagen synthesis is at its peak and the strength of the anastomosis depends on these newly organized collagen fibres (28). Biochemical parameters of anastomotic healing are reflected by the collagen content of perianastomotic tissues. Defining the level of hydroxyproline is a good method of evaluating the amount of tissue collagen. In this study, there was a significant difference in the concentration of hydroxyproline when the $\mathrm{O} 0$ and $\mathrm{O} 24$ groups and the sham group were compared.

Ozone therapy is supposed to change the levels of matrix metalloproteinases. Therefore, Shurska et al. (29) investigated the effect of ozone therapy on the levels of matrix metalloproteinases but could not prove Ozone therapy may have effects on collagen production and anastomotic healing through influencing the level of matrix metalloproteinases.

Histopathologic examination revealed significantly less necrosis and oedema in anastomotic segments from rats with ozone administration in comparison to the control group. This suggests that ozone therapy may cause a reduction in inflammation. Collagen deposition in the anastomotic segment was also significantly higher than in the control group, which also supports the beneficial effect of ozone therapy by promoting various growth factors, possibly because of an increased collagenase activity.

One of the limitations of the study was the animals in the sham and peritonitis groups received no placebo via the same route by which the solution of ozone was applied in groups $\mathrm{O} 0$ and $\mathrm{O} 24$. We do not know if the stress caused by this manipulation may have had some effect on the expected response. Having no antibiotic application may be supposed to be a further limitation of the study.

Ozone therapy blocks harmful effects of sepsis-induced injury on collagen synthesis during anastomotic wound healing. This therapy probably exerts its beneficial effects by improving antioxidant mechanisms, increasing tissue oxygenation, and promoting the production of various growth factors. In conclusion, ozone therapy has benefits on anastomotic healing of the colon in the presence of peritonitis. These effects can be attributed to its anti-inflammatory and antioxidative properties. Better outcomes might have been obtained if OT had been applied immediately after the operation.

Ethics Committee Approval: Ethics committee approval was received for this study.

Peer-review: Externally peer-reviewed.

Author contributions: Concept - B.E.; Design - B.E.; Supervision A.I.D., X.X.; Resource - T.E.; Materials - T.E.; Data Collection\&/or Processing - B.E., B.A.; Analysis\&/or Interpretation - A.İ.D.; Literature Search - B.E.; Writing - B.E., T.E.; Critical Reviews - A. İ.D.

Conflict of Interest: No conflict of interest was declared by the authors.

Financial Disclosure: The authors declared that this study has received no financial support.

\section{REFERENCES}

1. Vaneerdeweg W, Hendriks JMH, Lauwers PRM, Leven M, Eyskens EJM. Effects of gentamicin-containing sponges on the healing of colonic anastomoses in a rat model of peritonitis. Eur J Sur 2000;166:959-62. [CrossRef]

2. Sakallıglu AE, Yagmurlu A, Dindar H, Hasırcı N, Renda N, Deveci MS. Sustained local application of low-dose epidermal growth factor on steroidinhibited colonic wound healing. J Pediatr Surg 2004;39:591-5. [CrossRef]

3. Khalili TM, Navarro RA, Middleton Y, Margulies DR. Early postoperative enteral feeding increases anastomotic strength in a peritonitis model. Am J Surg 2001;182:621-4. [CrossRef]

4. Reijnen MMPJ, de Man BM, Hendriks Th, Postma VA, Meis JFGM, van Goor H. Hyaluronic acid-based agents do not affect anastomotic strength in rat colon, in either the presence or absence of bacterial peritonitis. Br J Surg 2000;87:1222-8. [CrossRef]

5. Hubbard WJ, Choudhry M, Schawacha G, Kerby JD, Rue LW $3^{\text {rd }}$, Bland KI, et al. Cecal ligation and puncture. Shock 2005;24:52-7. [CrossRef]

6. Ozen IO, Ekingen G, Taslipınar MY, Bukan N, Demirogulları B, Karabulut R, et al. Effect of melatonin on healing of colonic anastomosis in a rat model of peritonitis. Eur Surg Res 2007;39:122-7. [CrossRef]

7. Stubinger S, Sader R, Filippi A. The use of ozone in dentistry and maxillofacial surgery: A review. Quintessence Int 2006;37:353-9.

8. Nogales CG, Ferrari PH, Kantorovich EO, Lage-Marques JL. Ozone therapy in medicine and dentistry. J Contemp Dent Pract 2008;9:75-84.

9. Bocci V. The case for oxygen-ozone therapy. $\mathrm{Br} J$ Biomed $\mathrm{Sci}$ 2007;64:44-9.

10. Martinez-Sanchez G, Al-Dalain SM, Menendez S, Re L, Giuliani A, Candelario-Jalil E. Therapeutic efficacy of ozone in patients with diabetic foot. Eur J Pharmacol 2005;523:151-61. [CrossRef]

11. Guven A, Gundogdu G, Sadir S, Topal T, Erdogan E, Korkmaz A, et al. The efficacy of ozone therapy in experimental caustic esophageal burn. J Pediatr Surg 2008;43:1679-84. [CrossRef]

12. Lelyanov AD, Sergienko VI, Ivliev NV, Emelyanov VV, Guseva ED. Effects of sodium hypochlorite and ozone on healing of intestinal anastomosis in simulated strangulation colorectal obstruction. Bull Exp Biol Med 2004;137:103-5. [CrossRef]

13. Canbay E, Agachan B, Ozturk T, Giris M, Asoglu O, Balik E, et al. Dual inhibition of wound healing and oxidative process by montelukast in experimental colon anastomoses. Surg Innov 2010;7:248-55. [CrossRef] 
14. Verhofstad MH, Lange WP, van der Laak JA, Verhofstad AA, Hendriks T. Microscopic analysis of anastomotic healing in the intestine of normal and diabetic rats. Dis Colon Rectum 2001;44:423-31. [CrossRef]

15. Ehrlich HP, Hunt TK. The effects of cortisone and anabolic steroids on the tensile strength of healing wounds. Ann Surg 1969;170:203-6. [CrossRef]

16. Phillips JD, Kim CS, Fonkalsrud EW, Zeng H, Dindar H. Effect of chronic corticosteroid and vitamin A on the healing of intestinal anastomoses. Am J Surg 1992;163:71. [CrossRef]

17. Sumer A, Altınlı E, Senger S, Köksal N, Onur E, Eroğlu E, et al. Effect of pentoxifylline and vinpocetine on the healing of ischemic colon anastomosis: an experimental study. Ulus Travma Acil Cerrahi Derg 2011;17:482-7.

18. Inan $A$, Sen $M$, Sürgit $O$, Ergin M, Bozer M. Effects of the histamine H2 receptor antagonist famotidine on the healing of colonic anastomosis in rats. Clinics (Sao Paulo) 2009;64:567-70. [CrossRef]

19. Guzel S, Sunamak O, AS A, Celik V, Ferahman M, Nuri MM, et al. Effects of hyperbaric oxygen and Pgg-glucan on ischemic colon anastomosis. World J Gastroenterol 2006;12:1421-5.

20. Moran M, Ozmen MM, Duzgun AP, Gok R, Renda N, Seckin S, et al. The effect of erythropoietin on healing of obstructive vs nonobstructive left colonic anastomosis: an experimental study. World J Emerg Surg 2007;2:13. [CrossRef]

21. Cetinkaya Z, Esen K, Ozercan IH, Ustundag B, Ayten R, Ay-gen E. The effect of Bosentan on healing of colonic anastomosis. World J Emerg Surg 2006;1:37. [CrossRef]
22. Caglikulekçi M, Ozcay N, Orugg T, Aydog G, Renda N, Atalay F. The effect of recombinant growth hormone on intestinal anastomotic wound healing in rats with obstructive jaundice. Turk J Gastroenterol 2002;13:17-23.

23. Di Paolo N, Bocci V, Gaggiotti E. Ozone therapy. Int $J$ Artif Organs 2004;27:168-75.

24. Tandara AA, Mustoe TA. Oxygen in wound healing--more than a nutrient. World J Surg 2004;28:294-300. [CrossRef]

25. Aslan MK, Boybeyi Ö, Şenyucel MF, Ayva Ş, Kısa Ü, Aksoy N, et al. Protective effect of intraperitoneal ozone application in experimental ovarian ischemia/reperfusion injury. J Pediatr Surg 2012;47:1730-4. [CrossRef]

26. Teke Z, Aytekin FO, Aydin C, Kabay B, Yenisey C, Sacar S, et al. Effects of pyrrolidine dithiocarbamate on healing of colonic anastomoses in the cecal ligation and puncture model of intraperitoneal sepsis in rats. World J Surg 2007;31:200-9. [CrossRef]

27. Cihan AO, Bicakci U, TanderB, Rizalar R, Kandemir B, Ariturk E, et al. Effects of intraperitoneal nitroglycerin on the strength and healing attitude of anastomosis of rat intestines with ischemia-reperfusion injury. Afr J Paediatr Surg 2011;8:206-10. [CrossRef]

28. Caliskan B, Guven A, Ozler M, Cayci T, Ozcan A, Bedir O, et al. Ozone therapy prevents renal inflammation and fibrosis in a rat model of acute pyelonephritis. Scand J Clin Lab Invest 2011;71:473-80. [CrossRef]

29. Skurska A, Pietruska MD, Paniczko-Drezek A, Dolinska E, ZelazowskaRutkowska B, Zak J, et al. Evaluation of the influence of ozonotherapy on the clinical parameters and MMP levels in patients with chronic and aggressive periodontitis. Adv Med Sci 2010;55:297-307. [CrossRef] 